\title{
Functional Tests Group Identifier
}

National Cancer Institute

\section{Source}

National Cancer Institute. Functional Tests Group Identifier. NCI Thesaurus. Code C162007.

A character or string that represents a functional test group. 